\title{
Major Differences between the Revised 'Federal' and SNNP Regional State Family Codes
}

DOI http://dx.doi.org/10.4314/mlr.v11i2.7

Nigussie Afesha *

\begin{abstract}
There are two sets of family codes currently applicable in Ethiopia, the Revised Family Code and the family codes of regional states. These sets are compatible on numerous issues of family matters, and are also different on few issues. This comment outlines the major differences between the RFC with that of the SNNP Regional State Family Code. This comment indicates eight areas where the two codes have differences. The RFC has omitted the notion of betrothal whereas the SNNP regional state family law contains detail rules that govern it. Moreover, the RFC is silent regarding marriage celebrated in the cities where the RFC is applicable (i.e. Addis Ababa and Dire Dawa) while the SNNP Regional State Family Code does not apply to marriage celebrated outside the SNNP regional state. There is also variation between the RFC and the SNNP regional state family codes concerning relations in consanguinity and affinity, assessment of compensation following dissolution of marriage, proof of marriage, conditions to claim maintenance as well as salary and pension.
\end{abstract}

\section{Key terms}

Betrothal $\cdot$ Consanguinity $\cdot$ Affinity $\cdot$ Assessment of compensation · Proof of marriage $\cdot$ Maintenance $\cdot$ Salary and pension

\footnotetext{
* Nigussie Afesha, LL B, MA, Assistant Professor, College of Law and Governance, School of Law, Hawassa University. Email: nigussie.afesha12@gmail.com

I thank Dr. Beza Dessalegn and Mr. Bisrat Mulugeta for their comments. I am also grateful to Dr. Elias N. Stebek for his contributions toward the improvement of the comment.
}

\section{List of acronyms:}

CCI Council of Constitutional Inquiry

HoPR House of Peoples' Representatives

RFC Revised Family Code

SNNP Southern Nations, Nationalities and Peoples 


\section{Introduction}

The issue whether family law is a federal matter or an issue of a regional state has been a point of argument among academics and office holders. ${ }^{1}$ The Constitution expressly states the exclusive and concurrent power of the federal and the state governments, and leaves the residual powers for the state. ${ }^{2}$ According to the Constitution, all powers that are not expressly given to the federal government or States alone or concurrently to the federal government and the States are reserved to the States.

However, it should be noted that regional states may not have legislative power over residual powers in general because the Constitution limits the residual power of regional states to the enactment of civil laws. ${ }^{3}$ The federal government may enact civil laws when the House of Federation considers it essential for employing uniform law that can be used to establish and sustain one economic community. ${ }^{4}$ This ambiguity in residual power arrangement has prompted debate on the role of the federal and the regional governments in the enactment of family law. ${ }^{5}$ The other point of ambiguity relates to the enumeration of few basic essential conditions of marriage (consent and equality of the spouses) in the Constitutions of federal and regional states. Nevertheless, the Constitutions at federal and regional state levels, for example, fail to specify marriageable age and other issues, leaving these to be determined by subsequent

\footnotetext{
${ }^{1}$ The application of the Prime Minister's office to check whether the HoPR has the competence to enact a federal family code applicable nationwide is an example for this.

${ }^{2}$ Article 51, 52 and 55 of the FRDE Constitution.

${ }^{3}$ Id., Article 55(6) .

${ }^{4}$ Ibid. The FDRE Constitution does not enumerate those matters that fall under the phrase "to establish and sustain one economic community". Nor does it mention various legal concepts included under such phrase.

${ }^{5}$ As Assefa states:

"[a] petition was submitted from the Prime Minister's office to the HoF seeking its advice as to whether the HoPR has the competence to enact a federal family code applicable nationwide. If it has a competence, to what extent would this affect autonomy of the states to make laws on the same subject? The CCI investigated briefly Articles 52(1), 55(6) and 62(8) and ruled that enacting a family code is a state power on two counts. First, the enactment of a family code is intertwined with the culture, tradition, and religion of society. It is an aspect of diversity that needs regional protection. Second, reserve power belongs to the states and such power is not expressly granted to the federal government. This normally belongs to the states. But it briefly noted the importance of Article 55(6) although it stressed that it is not relevant to the issue at hand as the federal Constitution outlines the minimum standards under chapter three, the supremacy clause of Article 9 sub 2, 62 sub 1 and 84 sub 2 as enough safeguards in case the states enact family laws that contradict those minimum guarantees."

Assefa Fiseha (2006). Federalism and the Accommodation of Diversity in Ethiopia: A Comparative Study. (Netherlands: Wolf Legal Publisher) p. 338.
} 
legislation. ${ }^{6}$ However, the question as to whose mandate it is to regulate such details by legislation is controversial.

States can enact family law as long as this power (as an exclusive or concurrent task) is not expressly stated as the mandate of the federal government or the states. ${ }^{7}$ As a result, family law matters are within the domain of regional state powers, and it is pursuant to this power that most regional states have enacted their own regional family codes. ${ }^{8}$ In this regard, a petition was submitted from the Prime Minister's office to the HoF to check whether the HoPR has the competence to enact a federal family code applicable nationwide. On the basis of this request, the Council of Constitutional Inquiry (CCI) examined the pertinent provisions of the Constitution and ruled that enacting a family code is a matter that is left to the regional states. ${ }^{9}$

Yet, there is a 'Revised Family Code' (RFC) ${ }^{10}$ enacted by the HoPR in addition to the family codes of regional states. This law defines its subjects and the scope of its applicability. Paragraph 5 of the RFC's preamble provides that the territorial applicability of the RFC is restricted to those administrations that are directly accountable to the federal government. The law is applicable only in Addis Ababa and Dire Dawa city administrations. The above discussion shows the existence of two laws, which regulate the same subject matter, but having different territorial applicability. While the RFC applies in Addis Ababa and Dire Dawa, the regional states have enacted regional family laws, which are applicable in their respective territories.

These sets of laws are compatible with most of the rules that regulate family matters. However, there is some variation between the family laws at the federal and state levels. The following sections deal with the issues that have variation with the Revised Family Code in the context of SNNP regional state family code. The comment focuses on betrothal, impediment to marriage, proof of marriage, assessment of compensation, salary and pension.

\section{Betrothal}

Betrothal is an agreement whereby the fiancé and the fiancée agree to conclude marriage. ${ }^{11}$ It is, therefore, different from simple promise of marriage. If the

\footnotetext{
${ }^{6}$ See for example, Articles 34 (1) of the FDRE Constitution, Article 34(1) of the SNNP, Amhara and Tigray regional constitutions.

${ }^{7}$ Articles 51, 52 (2) and 55 of the FDRE Constitution.

${ }^{8}$ Tilahun, Teshome, (2001) Ethiopia: Reflection on the Revised Family Code of 2000, (unpublished paper).

${ }^{9}$ Assefa Fiseha, supra note, 5, p. 338.

${ }^{10}$ Proclamation No. 213/2000, Revised Family Proclamation, Federal Negarit Gazeta, Extraordinary Issue, No. 1/2000, Addis Ababa, 4 July 2000.

${ }^{11}$ Article 1(1) of the SNNP Regional State Family Code.
} 
agreement of betrothal is consistent with the usage of the place where it is celebrated, it has binding effect. Even though betrothal was embodied in Articles 560 to 576 of the 1960 Code of Ethiopia, it is omitted under the RFC, whereas the SNNP regional state family code contains detail rules that govern it. $^{12}$ The reason behind the omission of betrothal in the RFC is most likely because betrothal is not a precondition to marriage, and betrothal does not take the conclusion of marriage for granted. ${ }^{13}$ Tilahun states that:

"the institution of betrothal is not found in the [Revised Family Law]. The reason advanced by the drafter for so doing was that in view of the Ethiopian diversity, the wishes of retaining betrothal in the law as a uniform practice would not serve meaningful purpose”. ${ }^{14}$

Although betrothal does not necessarily lead to conclusion of marriage, it is still an important cultural component in many parts of the country. Regional family codes thus embody betrothal. The SNNP regional state family code defines betrothal as an agreement between fiancé and fiancée to conclude marriage in the near future. ${ }^{15}$ This agreement is based on exclusive mutual consent of the future spouses. ${ }^{16}$ Traditionally, betrothal was mostly arranged between the families and often accompanied by an exchange of property and the formation of alliances. The SNNP regional state family code embodies a reform in this regard and the families of the betrothed couple may give consent to the betrothal although it does not change the agreement between the fiancée and fiancé. ${ }^{17}$

The SNNP regional state family code envisages the conclusion of marriage within a year following betrothal. It is to be noted that a fiancé or fiancée cannot arbitrarily break his/her promise to marry, and the one who arbitrarily abandons his/her plan to marry is obliged to pay compensation. ${ }^{18}$ The compensation involves moral and material damages. ${ }^{19}$ The extent and amount of material compensation will be decided based the evidence produced whereas, (in contrast to the Civil Code $^{20}$ ), the maximum amount of moral compensation is Ten

\footnotetext{
${ }^{12}$ Id., Article 1 to 10.

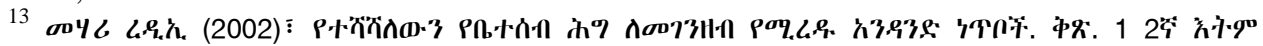
7d. 13

${ }^{14}$ Tilahun, Teshome, supra note, 8, p 6.

${ }^{15}$ See Article 1(1) of the SNNP ${ }^{15}$ See Article 1(1) of the SNNP Regional State Family Code Family Code.

${ }^{16}$ Id., Article 1(2).

${ }^{17}$ Ibid.

${ }^{18}$ Id., Article 8.

${ }^{19}$ Ibid.

${ }^{20}$ See Article 2116(3) of the Civil Code. According to the Civil Code, as a rule, moral harm which affects one's feeling may not be made good by way of damages unless there is clear stipulation to this effect. Even in the existence of clear stipulation in the law that necessitates moral damage to be compensated in monetary terms, the Civil Code limits the
} 
Thousand Birr. ${ }^{21}$ Even though the regional family code is silent with regard to the determination of material compensation, it can be decided based on the financial cost incurred by the victim of the cancellation of betrothal.

\section{Marriage celebrated outside the Region}

Family has been understood as an essential element to wholesome human life ${ }^{22}$ and is believed to be the cradle of human society. It is "of great legal interest because of the decisive role it has historically played in raising and socialization of children and in the mutual economic support of its members."23 Marriage, one of the essential means to form a family, is found practically in all human societies, "without which there would be neither civilization nor progress." 24 Every state thus embodies laws that recognize and regulate marriage. The laws determine the factors involved in the validity of the marriage. As a rule, "a marriage which is valid under the law of the State where it is entered into will be likely recognized as valid by another State". ${ }^{25}$

However, there is also a possibility that marriage, which is valid under the law of the state where it is entered into, may not be recognized as valid by another state. This could happen if marriage is voidable as a matter of public policy in the second state. ${ }^{26}$ In other words, marriage may not be recognized as valid in the place where spouses live even if it was valid under the laws of the state in which it was concluded. For instance, "in countries where bigamy is prohibited, polygamous marriages may be regarded as null and void even though this is recognized as valid in the state in which the marriage is celebrated". ${ }^{27}$ In a state where polygamy is barred as a matter of public policy, the bigamous spouses are not entitled to the legal protections accorded to legal wives under such law. ${ }^{28}$

In the context of Ethiopia, the RFC and the SNNP regional state family code give recognition for marriage celebrated outside the country. Both family codes

maximum amount of moral compensation to be awarded for the victim not to exceed One Thousand Ethiopian [Birr].

${ }^{21}$ Article 8(4) SNNP state Family Code.

${ }^{22}$ Bruce W. Frier \& Thomas A.J. McGinn (2004), A Casebook on Roman Family Law, published by Oxford University Press, New York, p. 3.

${ }^{23}$ Ibid

${ }^{24}$ Shoshana Grossbard-Shechtman (2003), "Marriage and the Economy in the Shoshana”, A Grossbard-Shechtman (ed.) Marriage and the Economy: Theory and Evidence from Advanced Industrial Societies, Cambridge University Press, Cambridge, p. 1.

${ }^{25}$ Barbara Stark (2005), International Family Law: An Introduction, Ashgate Publishing Limited USA p. 17.

${ }^{26}$ Ibid.

${ }^{27}$ Ibid.

${ }^{28}$ Ibid. 
recognize marriage celebrated abroad, in accordance with the law of the place of celebration, so long as it does not contravene with public moral. ${ }^{29}$ Although the RFC and the SNNP regional state family code have similar provisions on marriage celebrated abroad, they have variation with regard to marriage celebrated in different parts of Ethiopia. The RFC remains silent regarding marriage celebrated outside the cities where the RFC is applicable. On the other hand, the SNNP regional state family code states that marriage celebrated outside the regional state but within Ethiopia in accordance with the law of the place of celebration shall be valid in the region so long as it does not contravene public morality of the SNNP regional state. ${ }^{30}$ According the SNNP regional state family code, there is a possibility that marriage celebrated outside the territory of the SNNP regional state (in one of the eight regional states of Ethiopia including Addis Ababa and Dire Dawa city administrations) may not be recognised as valid marriage. This shows that the regional state has the authority to determine the validity of marriage based on the grounds of public morality, even though it is validly concluded in other regional states and city administrations where they were celebrated.

For instance, marriage between an uncle and a niece or an aunt and a nephew is voidable as a matter of public policy in the SNNP regional state and it is prohibited and voidable under the SNNP regional state family code. Hence, such marriage shall not be recognized in SNNP regional state if it is allowed in any of the regional states.

\section{Sources of relationship by consanguinity and affinity}

Marriage has been subject to the regulatory intervention of the government, ${ }^{31}$ which through the legislator, inter alia, prescribes marriageable age, the procedure for entry and exit from marriage and the rights and obligations arising from the marital relation. ${ }^{32}$ More importantly, the family law sets out the essential conditions the future spouses need to comply with, otherwise called prerequisites for a valid marriage. These prerequisites to a "marriage fall into three categories: eligibility, consent and formalities requirement."33 The eligibility criteria determine who is qualified to enter into marriage. ${ }^{34}$ Most

${ }^{29}$ See Articles 5 and 15(1) of the Revised and the SNNP regional state family codes respectively.

30 Article 15(2) of the SNNP Regional State Family Code reads: "Marriage celebrated outside the Region in accordance with the law of the place of celebration shall be valid in Region so long as it does not contravene public moral.”

${ }^{31}$ Sanford N. Katz (2011), Family Law in America, Oxford University Press, New York, p. 35.

${ }^{32}$ Ibid.

${ }^{33}$ Stark, supra note, 25 26, p. 15

${ }^{34}$ Ibid. 
countries impose limits based on laws on consanguinity and may prohibit close relatives from marrying. However, "the idea of 'close relatives' has different meanings in different cultures". ${ }^{35}$ "The law lists those individuals who are prevented from marrying due to their being in the prohibited degrees of relationship. ${ }^{36}$ The most commonly prohibited relationships are those between direct lineal kin (for example, parents and children) and between siblings. Generally speaking, there are two types of prohibited degrees, and they clearly reflect the question 'who can marry whom?' The first category of prohibited degrees of relation is relation that arises from consanguinity, that is, relationships by blood. The second category of prohibited degrees of relation arises from affinity, which is created by marriage. If the partners are within the prohibited degrees of relationship, they are not allowed to establish conjugal relation.

There is variation between the RFC and the SNNP regional state family codes with regard to the regulation of family relationship. The RFC indicates that relationship by consanguinity shall be of no effect beyond aunt and uncle in the collateral line.$^{37}$ However, the SNNP regional state family code extends the degree of relationship by consanguinity, in the collateral line, to seven generations (degrees). ${ }^{38}$ Unlike the RFC, the SNNP regional state family code gives effect for relationship by consanguinity in the collateral line, which goes beyond aunt and uncle. Even if it is not culturally expected to occur in Ethiopia, marriage between cousins in Addis Ababa or Dire Dawa, for example, does not violate Article 8(2) of the Revised Family Code, while such marriages are prohibited in SNNP regional state.

Bonds of affinity derive from marriage as stipulated under both the RFC and the SNNP regional state family code. Under both laws, the bond of affinity exists in the direct line, between a person and the ascendants or descendants of his spouse. ${ }^{39}$ This bond also exists between a person and the collaterals of his/her spouse. The RFC limits the bond of affinity in the collateral line to a sister of one's wife, or a brother of one's husband. ${ }^{40}$ However, SNNP regional

${ }^{35}$ Ibid.

${ }^{36}$ Me Rodgers (2004) Understanding Family Law, Cavendish limited Publisher, Great Britain, p. 16.

${ }^{37}$ See Article 8 of the Revised Family Code.

${ }^{38}$ See Article 18(2) of the SNNP Regional State Family Code. According to the SNNP Regional State Family Code, the degree of relationship by consanguinity in the collateral line shall be calculated by counting seven generations in the two lines starting from the common ancestors and by adding the two series of degrees.

39 Article 9(1) of the Revised Family Code and Article 19(2) of the SNNP Regional State Family Code.

${ }^{40}$ Article 9(2) of the Revised Family Code. 
state family code extends affinal kinship to third degree in the collateral line. ${ }^{41}$ This shows that marriages in Addis Ababa and Dire Dawa city administration between a man and the aunt of his ex-wife (whom he has divorced), and a woman and the uncle of her ex-husband do not violate Article 9(2) of the Revised Family Code, while such marriages are prohibited in SNNP regional state. Hence, this constitutes another difference between the two codes.

\section{Grounds and mode of compensation}

Marriage is assumed to be a long-lasting union between a man and a woman. ${ }^{42}$ However, the dissatisfaction of one of the spouses suffices to terminate the marital relation. It can be dissolved solely by one of the spouses with the concurrence of a court. Divorce is the legal dissolution of a marriage ${ }^{43}$ which could be fault based or no-fault divorce. Under no-fault divorce, there is no need to establish fault. ${ }^{44}$ On the other hand, when divorce is fault-based, a spouse is required to assert that dissolution is sought due to fault committed by the other spouse. $^{45}$

In Ethiopia, several regional states incorporate no-fault divorce. ${ }^{46}$ This means a spouse who seeks divorce is not obliged to prove the occurrence of fault and to whom the fault is attributed. Although mentioning the occurrence of fault is not a compulsory requirement, a spouse who states the occurrence of fault and consequently sustains damage due to the fault committed by the other spouse can claim compensation. In this regard, both the RFC and SNNP regional state family codes are compatible, because under both codes, the court may, where justice so requires, order compensation if the cause of divorce is imputable to one of the spouses. ${ }^{47}$ Thus, the spouse, who sustains damage due to the fault of the other spouse, is entitled to appropriate remedy, which corresponds to the nature of a fault committed by the other spouse. However, the RFC does not

${ }^{41}$ See Article 19(2) of the SNNP regional state Family Code. It should be noted that the SNNP regional state family law is silent how the degree of affinal relation in the collateral line can be calculated. But, one can take, mutatis mutandis, the rule that is used to calculate the degree of relationship for consanguinity. The degree of relationship shall be calculated by counting third generations in the two lines starting from the common ancestors and by adding the two series of degrees

${ }^{42}$ Cohen Lloyd (1987), “Marriage, Divorce, and Quasi Rents”; Or, "I Gave Him the Best Years of My Life”, The Journal of Legal Studies, Vol. 16, No. 2, p. 267.

${ }^{43}$ Id., p. 274.

${ }^{44}$ Ibid.

${ }^{45}$ Ibid.

${ }^{46}$ See Articles 77(3) \&81(3) of the Revised Family Code; Article 86(3) \&90(2) of the SNNP Regional State Family Code; Article 88(3) \& 92(2) of the Amhara Regional State Family Code.

${ }^{47}$ Article 93(4) SNNP Regional State Family Code. 
indicate the kinds of damage that may entail legal liability and its corresponding modes of compensation.

In contrast, the SNNP regional state family code states the types of harm that justify legal liability and the mode of compensation. The SNNP regional state family code requires the spouse who claims compensation to prove the occurrence of fault recognized as fault that entails liability under the law and prove that the fault is attributable to the other spouse. For the purpose of compensation, the SNNP regional state family code, associates fault with violation of personal obligations of spouses. ${ }^{48}$ Personal obligations of spouses are the reciprocal rights and duties of the spouses ${ }^{49}$ that are unique to and stem from the institution of marriage, which are expected to be carried out by the spouses, while they are in matrimony. These obligations cannot be set aside by the agreements of the spouses; $;^{50}$ and they include the obligation to support, respect and assist, obligation to cohabit, obligation to owe fidelity, and the obligation of joint management of the family. ${ }^{51}$ Failure to comply with these personal effects of spouses amounts to fault, which causes legal liability. ${ }^{52}$

For the purpose of the family code of the SNNP Regional State, the occurrence of fault shall be judged against the violation of personal effects of marriage. Unlike the RFC, the SNNP regional state family code classifies faults that emanate from violation of personal effects of marriage into two categories. The first category of fault arises from failure to carry out obligation to support, respect and assist. ${ }^{53}$ The second category arises when one of the spouses fails to carry out his/her obligation to cohabit without good cause or/and if he/she violates fidelity to the other spouse. ${ }^{54}$ Both categories of fault entitle the aggrieved party to different remedies that are determined based on the type of fault committed by the spouses, and the nature of the fault is considered in assessing compensation. The remedies may be monetary compensation or awarding of a higher portion from common property. ${ }^{55}$ Under the first category of fault, a victim spouse is entitled to monetary compensation that does not exceed ten thousand Birr. The court may award higher portion of property to the victim from the common property if the second category of fault is committed. ${ }^{56}$

\footnotetext{
${ }^{48}$ Id., Article 94(2).

${ }^{49}$ See Article 42(2) of the RFC and Article 51(2) of the SNNP Regional State Family Code.

${ }^{50}$ Articles 58(2), 61(2), 62(2) of the SNNP Regional State Family Code.

${ }^{51}$ Id., Article 58(2) to 65.

${ }^{52}$ Id., Article 94(2).

${ }^{53}$ Id., Article 94(2) (a).

${ }^{54}$ Id., Article 94 (2) (b).

55 Id., Article 95.

${ }^{56}$ Id., Article 95(3).
} 


\section{Proof of marriage}

A spouse, who alleges that $\mathrm{s}$ /he has valid marriage with a given person, has to prove its existence, and must ascertain the same with appropriate evidence. Both the RFC and SNNP regional family codes recognize certificate of marriage as a conclusive evidence of marriage. ${ }^{57}$ In the absence of marriage certificate, both family codes allow marriage to be proved by the possession of status of spouses. ${ }^{58}$ The codes provide that if "it is difficult to prove marriage by producing the certificate of marriage due to the fact that the marriage has not been registered or such register has been lost, it shall be proved by the possession of status of spouses". ${ }^{59}$

However, the laws take different positions on the types of evidence that can be produced as proof marriage by possession of status. The RFC merely mentions the possibility to prove the conclusion of marriage through possession of status without indicating the type of evidence. There is no express or implied prescription regarding the type of evidence which can be inferred from the RFC. On the other hand, the SNNP regional state family code specifically requires marriage to be proved -in the absence of certificate of marriage- through possession of the status of spouses by producing four witnesses who have attended the celebration of the marriage. ${ }^{60}$ This can be interpreted as requiring the witnesses to prove their presence during the marriage celebration.

\section{Salary and pension}

Divorce not only changes the legal status of spouses but also terminates financial relations that exist between them. Although personal effects of marriage automatically end when the court pronounces divorce, pecuniary effects of marriage are yet to be determined by court. This leads to liquidation of property. The first task of liquidation of property is identifying the common and personal property of spouses. ${ }^{61}$ The mere fact of marriage does not affect the rights of property owners, or the right to continue acquiring property for the use and benefit of the individual spouse. This right to individual property applies if

${ }^{57}$ Article 94 of the Revised Family Code and Article 106 of the SNNP Regional State Family Code.

${ }^{58}$ Article 95 of the Revised Family Code and Article 107 of the SNNP Regional State Family Code.

${ }^{59}$ Ibid.

${ }^{60}$ Article 109 (1) (2) of the SNNP Regional State Family Code.; (Emphasis added)

61 Nigussie Afesha (2016), "Legal and Practical Aspects of Post-Divorce Issues with Particular Emphasis on Liquidation of Property and Compensation in SNNPR Courts: A Case Study", Proceedings of the $37^{\text {th }}$ Annual Research Review Workshop, April 29-30 2016, pp. p 26. 
spouses can show sole legal or beneficial title. On the remaining property, the law takes the presumption that all property shall be deemed to be common property even if it is registered in the name of one of the spouses. ${ }^{62}$

Therefore, spouses are expected to list-out their personal and common properties along with the evidence that proves their claims. There might be disagreement in listing which property is personal and common property of the spouses. After several years of marriage, it may be difficult to ascertain who owned what before marriage. ${ }^{63}$ In the event of such disagreement, two considerations can be used, i.e. (a) the time when, and (b) the way how the property was acquired.

Property, which a spouse had before or at the time of concluding the marriage, remains his or her personal property. ${ }^{64}$ Property, which a spouse has acquired during marriage through gifts or inheritance, also remains individual property. ${ }^{65}$ Moreover, personal property made by the contract of spouses remains their respective personal property. ${ }^{66}$ Furthermore, property acquired by onerous title during marriage shall also remain personal property provided that the property is approved by court to remain personal property of such spouse. ${ }^{67}$

On the other hand, all properties acquired by either spouse during the marriage, with exceptions of gifts and inherited property, are marital property, regardless of the name that is designated as owner or property. ${ }^{68}$ Such common property of the spouses includes all forms of property or income gainfully acquired by the spouses either separately or together in the course of their marriage. These include the fruits or income derived from the goods they own personally or jointly or derived from personal effort. ${ }^{69}$

Although the RFC does not specifically answer whether salary is common property, one can justifiably infer that salary is regarded as common property of the spouses while the spouses are in the marriage. This is because the RFC provides that all income derived by personal efforts of the spouses or from their common or personal property shall be common property of the spouses. ${ }^{70}$ With regard to pension, the contribution of the employee deducted from salary can be regarded as common property of the spouses, at least, while they are married. Since pension benefits are received upon retirement, divorce that predates

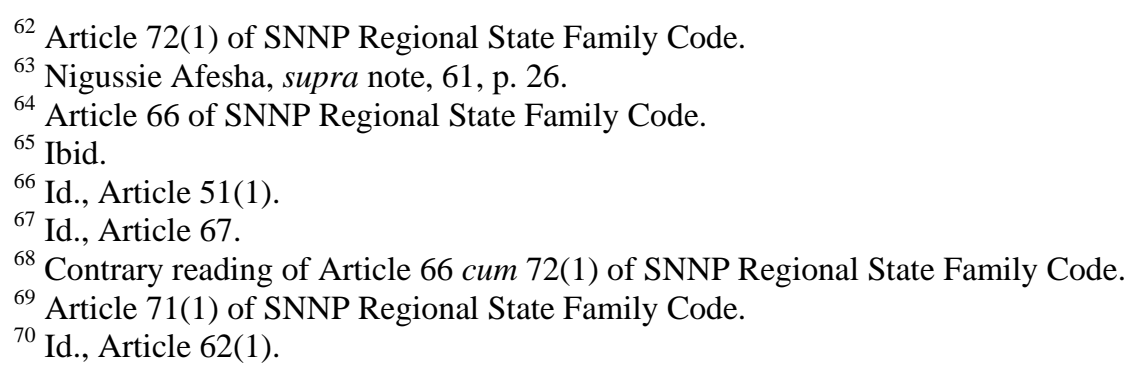


retirement can raise the issue whether the claim of the other spouse over the pension benefits ceases upon divorce. In this regard, Wondwossen states:

It is appropriate now to examine whether pension benefits should be part of the property to be divided as a consequence of divorce, and how the valuation is to be made. Generally, the amount to be deposited to the Civil Service Fund, from which retirement pensions are paid, is ten percent of the salary of the public servant. The public servant contributes four percent, and the remaining six present is contributed by the employer. In so far as the employee contribution is made during the marriage, there is no doubt that the four percent contributed each month is a marital property. This is because the contributed money is part of the salary, which is a common property of spouses ${ }^{71}$

Wondwossen's argument gives recognition to the pension contribution deducted from a spouse's salary. However, the law seems to have given priority to administrative efficiency rather than equity. The RFC and the SNNP regional state family codes provide straightforward solution for this. According to both laws, salaries and pensions of the spouses shall not, upon divorce, be partitioned between the spouses, and they shall rather remain personal property of the spouses who derive the income and in whose name the pension is deposited. ${ }^{72}$ As a result, they are not subject to partition during the divorce proceedings. ${ }^{73}$

\section{Impediment to irregular union}

The capacity to marry relates to the question: "who can marry and whom?". ${ }^{74}$ Such capacity requirements regularly specify minimum age and appropriate conditions of mental and physical health. This often prohibits, for instance, incestuous marriages or polygamy. ${ }^{75}$ Hence, most states impose limits based on their laws on consanguinity and age, and may prohibit between close relatives or by persons under eighteen years of age. ${ }^{76}$ Such requirements are not specifically stipulated with regard to irregular union.

It is argued that the preconditions to valid marriage are applicable to irregular union. The RFC, which states the preconditions for valid marriage, does not indicate the applicability of such requirements for irregular union ${ }^{77}$ other than

\footnotetext{
${ }^{71}$ Wondwossen Demissie, (2007), "Implementation problems of the Revised Family Code”, Berchi (Annual Journal of EWLA), Issue 6, pp. 1-52, p. 13.

${ }^{72}$ Article 104 (1) of the SNNP Regional State Family Code .

${ }^{73}$ Ibid

${ }^{74}$ Frier \& McGinn, supra note 22, p. 26

${ }^{75}$ Ibid.

${ }^{76}$ Stark, supra note, 25, p. 15.

${ }^{77}$ See Articles 6 to 16 cum 98-106 of the RFC.
} 
raising the issue of affinity. ${ }^{78}$ The RFC clearly stipulates that an irregular union will not create any bond of affinity between the man and the relatives of the woman, and the same holds true between the woman and the relatives of the man. However, the relationship of affinity could be an impediment to irregular union. According to the RFC, it is imprecise whether consanguinity impedes irregular union. Nevertheless, it can be argued that if affinity is an impediment to irregular union, for stronger reason, consanguinity should also constitute an impediment to irregular union.

In this regard, the SNNP regional state family code clearly puts additional preconditions to irregular union. The SNNP regional state family code acknowledges the applicability of some of the preconditions to valid marriage for irregular union as well. ${ }^{79}$ The SNNP regional state family code states that the provisions concerning impediments to marriage, which are related to age limit and prohibited degrees of relationship are also applicable in the case of an irregular union. ${ }^{80}$ By logical extension, the SNNP family law excludes the applicability of the other validity requirements of marriage to irregular union.

\section{Maintenance}

There is mutual obligation on family members to maintain one another. ${ }^{81}$ In this regard, Wondwossen states that "the obligation to supply maintenance exists between spouses, relatives by affinity and relatives by consanguinity" ${ }^{82}$ The notion of maintenance also illustrates unequal status of individuals in society. ${ }^{83}$ Maintenance is an amount of monetary support paid to the financially dependent individual based on a number of factors. ${ }^{84}$ The purpose of maintenance is to prevent financial and social hardship and disruption that may be encountered by a financially dependent person. The court may order maintenance if a person does not have enough income, property, or both to support his/her reasonable

\footnotetext{
${ }^{78}$ Article 100(2) of the SNNP Regional State Family Code.

${ }^{79}$ Id., Article 114.

${ }^{80}$ Ibid.

${ }^{81}$ Frier \& McGinn, supra note, 22, p. 3.

${ }^{82}$ Wondwossen Demissie, supra note 71, p. 13.

${ }^{83}$ This can be inferred from the precondition required by law (to claim maintenance). In this regard, Article 201 of Revised Family and Article 216 of the SNNP Regional State Family Code provide that " $[t]$ he obligation to supply maintenance shall not exist unless the person who claims its fulfillment is in need and not in a state of earning his livelihood by his work." There is discrepancy between the Amharic and English version of Article 216 of

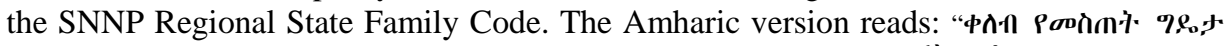
+6.9\%, Poq,

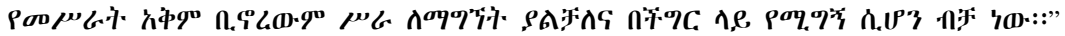

${ }^{84}$ Article 202 of the Revised Family Code and Article 216 of the SNNP Regional State Family Code.
} 
needs, or if the claimant is unable to support him/herself by his/her labour or work. Reasonable needs are measured not by a community's or society's poverty level in general, but by the standard of living the claimant has during the filing of the claim.

The RFC imposes an obligation to supply maintenance between persons who are related either by consanguinity or affinity. The SNNP regional state family code also shares the same notion. The RFC sets two conditions to claim maintenance: the claimant must prove that he/she is needy, and must also prove that he/she is not in a state of earning livelihood by her/his work. Pursuant to the RFC, a person who is needy but in a state of earning her/his livelihood by her/his work is not eligible to claim maintenance.

The SNNP state family code, embodies these conditions of maintenance stipulated in the RFC, and further includes one more possibility to claim maintenance. Pursuant to the SNNP state family code, the claimant can claim maintenance so long as $\mathrm{s} / \mathrm{he}$ is needy irrespective of whether $\mathrm{s} / \mathrm{he}$ is in a state of earning her/his livelihood by her/his work. According to the SNNP family code, a person who is needy but in a state of earning her/his livelihood by her/his work is eligible to claim maintenance. ${ }^{85}$

\section{Concluding remarks}

In Ethiopia, there are two sets of family codes, which have different territorial applicability. It is not because the FDRE Constitution assigns concurrent powers for the two codes. Rather, this is duly caused by the distribution of power enshrined in the Constitution with regard to family law. As discussed in the sections above, the two family codes have different territorial scope of applicability.

As highlighted in this comment, there are certain major differences between the RFC and the SNNP regional state family code. Although these laws are compatible with regard to most rules that regulate family matters, there are matters in which the two codes are at variance and at times inconsistent in terms of content. The differences -as indicated above- include betrothal, impediment to marriage, proof of marriage, maintenance, and assessment of compensation following divorce. Such variation can be inevitable and appropriate where it is caused by the divergence of the realities at the regional state level. However, some of the variations such as the mode and standard of proof for irregular union could have had harmony between the two family codes.

${ }^{85}$ See the Amharic version of Article 216 of the SNNP Regional State Family Code. 